\title{
Micro-credentialing as making and doing STS
}

\author{
Michaela Spencer \\ College of Indigenous Futures, Arts and Society, Charles Darwin University \\ michaela.spencer@cdu.edu.au
}

Keywords: Micro-credentials; Indigenous; Yolnu; community-based research; research services; design; inquiry into inquiry; making and doing; STS

\begin{abstract}
In this paper I tell stories of collaborative design work, developing research micro-credentials suitable for Indigenous community-based researchers working in their home communities in North East Arnhem Land, Australia. These credentials are coming to life within growing microentrepreneurial economies that are beginning to take root within Aboriginal communities in northern Australia. While there is significant critique of these forms of economy and the socio-technical infrastructures through which they extend, here I set my inquiry down amidst the mundane practices of community research services design, and particular moments or 'turning points' in the emerging life of these technologies. I inquire into the arrangements and practices of these initial design activities, proposing such work as 'making and doing STS' and reflecting on this form of STS empirics.
\end{abstract}

\section{Introduction}

\begin{abstract}
STS Making and Doing is... a mode of scholarship that involves attending not only to what the scholar makes and does but also to how the scholar and the scholarship get made and done in the process. (Downey \& Zuiderent-Jerak, 2016, p. 225)
\end{abstract}

As an emerging thread within the field of Science and Technology Studies (STS), Making and Doing is concerned with STS scholarly outputs other than journal articles and books, and which have an impact in the situations where they came into being. It draws attention to the considerable social, material and conceptual labour that is associated with such work, and to the kinds of objects that these situated and practical endeavours produce. However, STS Making and Doing takes on a unique turn in situations where STS scholars find themselves in the position of designing research services products ${ }^{1}$ as participants in as the everyday business of their academic activities.

In Australia, I work as part of the GroundUp group in the Northern Institute at Charles Darwin University (CDU) in the Northern Territory. ${ }^{2}$ We undertake contract research, often working collaboratively with Indigenous Elders and researchers as well as staff from government departments, designing responses to various problems emerging in the on-going collective life of Northern Territory Indigenous communities and their relation to governments.

\footnotetext{
1 The term 'research services products' refers to entities which emerge within circulate and carry value within market economies oriented around the provision of research services. Universities participate in these markets and do so through partnering with other key authorities and providers. Increasingly, this includes partnering with Indigenous researchers in remote Australian communities.

2 See http://groundup.cdu.edu.au/
} 
Through the conditions of our contracts with the government and non-government organisations funding these inquiries, we are often obliged to deliver quite specific research services products. This includes, for example, processes for evaluating Indigenous healthcare programs (Spencer et al., 2019), digital interfaces for learning Aboriginal languages (Bow, 2019), and toolkits guiding government engagement practices in Aboriginal communities (Spencer and Christie, 2020). However, the delivery of these research services products does not preclude other possibilities of learning and inquiry; indeed, these sites of collective research practice provide unique opportunities to discern and generatively articulate relations of sciences, technology and society which we are involved in and in the process of bringing to life. To be involved in work of this order implies what Helen Verran calls a form of 'relational empiricist inquiry' (Verran, 2001, 2013). A research practice that extends beyond the delivery of contracted products and also includes "inquiring into the workings of the collective politico-epistemic practices of our research - [or an] inquiry into inquiry" (Verran, as quoted in Gibson, 2016).

In this paper, I tell three ethnographic stories about contributing to assemblage (Law, 2004) of a micro-entrepreneurial services product: community-based research services. This product is coming to life in market-mediated networks, exemplifying a growing global microentrepreneurial economy that is beginning to take root within Aboriginal communities in northern Australia just as significantly as it is becoming embedded in new forms of social life in many other places (Baporikar, 2015). It responds to increasing numbers of Indigenous entrepreneurs who recognise research and consultancy services as of value within 'gig economies' that will allow them flexible working hours and the ability to earn a salary while continuing to live in their home communities, and to an increasing interest in the part of universities and other agencies to partner with Indigenous knowledge and culture services providers.

The coming to life of this object of 'community-based research services' in a particular Aboriginal community in East Arnhem Land has involved a distributed array of participants: teams of community based Indigenous researchers, who have for many years worked in the community as consultants and cross-cultural facilitators; a local Indigenous research organisation that supports the work of these on-ground teams; university collaborators, such as our GroundUp team; government and other funding agencies, senior knowledge authorities overseeing the emergence of new practices and entities in their communities, and many others. However, the particular entry point I take to the assembling of 'community-based research services' is via a new participant within this distributed collective - research micro-credentials ${ }^{3}$.

I've worked with our Indigenous collaborators in remote communities, and others on the GroundUp team, to collaboratively design these new credentials (or digital badges ${ }^{4}$ ) to be awarded in recognition of intercultural research skills which are alive and well in many Australian places, but otherwise invisible within the mainstream academy. These micro-credentials being explored by Charles Darwin University as a novel form of qualification able to be marketed to local customers i.e. Indigenous students and micro-enterprise entrepreneurs living in remote Aboriginal communities. As new participants in arranging market ready community-based research services, these credentials play an important role in enhancing the market viability of research services on the ground and educational services in the university. However, the gradual assembling and coming together of these new objects has taken a few twists and turns.

\footnotetext{
3 See https://iri.cdu.edu.au/credentials/ and https://www.youracclaim.com/organizations/charles-darwin-university/ collections/indigenous-researcher-initiative/badge_templates

4 These micro-credentials are designed to be accessed and viewed via an online platform. They can be printed out as certificates as achievement, but are more commonly referred to as 'digital badges' - awards that are designed to be visible in virtual environments.
} 


\section{Story One: Desiging badges in the university}

A few of us from the GroundUp team headed across campus to CDU's Innovative Media Production Studio (IMPS). We were to meet with the team that would be developing the university's first batch of micro-credentials, and brainstorm possibilities for new digital badges that could be offered within the university. The IMPS presenter sat at the front of the room and flicked through web pages projected up on a clean white studio wall, taking us through the elements of the digital platform where the badges would be hosted and the employment databases to which they were linked. At first it felt very difficult to discern a connection between collaborative research work we do out in communities and this discussion sitting in the studio space. She told us that the university had recently entered into a contract with the company running the micro-credential hosting platform, and had purchased a certain number of 'seats' - which represents the number of students able to register a profile on the platform, and earn micro-credentials for their achievements.

We started to throw a few ideas around about micro-credentials that could be developed. There would be ways to use micro-credentials to recognise participation in Indigenous language courses. At the end of these 6-week fee-for-service courses, instead of a certificate of attendance, students could receive a micro-credential signifying their participation. Or maybe we could push this further. Instead of just being accredited for participation, they could complete a final assessment and be credited for completing a component of a unit that could count towards a more substantial degree - a Diploma or Bachelors. But who should be awarded these credentials? Perhaps not only the attending fee-paying students, but also the Yolnu language teachers who were leading the classes. They could also receive a micro-credential recognising their teaching skills, often developed out of Western educational systems, but of value within the contexts of these courses and interests of students to learn and speak Indigenous languages.

In our team of GroundUp researchers, we had been looking for better ways to recognise the researchers and consultants that we worked with on various projects in remote Aboriginal communities. While there were opportunities for Indigenous students and teaching staff to come into the university, this was not always easy to achieve, or what everyone wanted. It was recognition at home, that was more sought after. For years these remote researchers been helping university-based staff coming out to communities and using their knowledge and expertise, whilst then seeing those people return to their university to receive PhDs or complete publications and receive promotions, while Indigenous researchers and consultants in communities did not receive such accolades for skills attained, or long service provided.

We came up with two possible badges. One was the 'Senior Indigenous community-based researcher.' This is a badge recognising that there are people who have been working for years as community consultants, who don't need training but are deserving of recognition. This badge could offer recognition of prior learning. The second badge for 'Indigenous community-based research', is designed for younger people who are not so experienced, but may be looking for opportunities to draw from their own cultural knowledge in place, while also learning on the job how to work with people from the university on funded research projects. These students might also be interested in pathways into the university that do not involve full immersion in the university culture straight away, but can be supported to first start their studies by working on country with family before seeking to take on a university course. 
These were the two badges we started with, and for which we began to develop templates and skills and assessment evidence criteria. All the trappings required by the online platform hosting the badges, and connecting between authorising institutions (CDU) and the potential earner, in their communities.

A lot of the development work happening in this part of the process, had to do with lining up potential applications and awardees with systems for registering them and managing their data in an arrangement that integrated awardees into an international network connected to various other data management systems. These 'digital badges' are credentials that have agency in the workings of a national economy expressing the neoliberal ideology that the solution to disadvantage is the inclusion of underprivileged or excluded people into market relations (Howard-Wagner et al., 2018). However, it soon became clear to us that that in establishing and administering the badges as a CDU qualification, and an unconventional education services product could be marketed, was only half the work that needed to be done. The other-side of the necessary work only slowly, and confusingly, became clear.

\section{Story Two: Designing badges on Elcho Island}

On a research trip to Galiwin'ku, Elcho Island, we drive around from house to house, hopping in and out of the 4WD. The local team of researchers I'm working with are a cheery bunch - experienced senior women sitting in the front seat, younger researchers in the back, and various children and pets wriggling in between.

While going about our work for one of our research projects, we're also talking about these new micro-credentials, these badges that CDU is starting to develop and which might be interesting and helpful for researchers in the community. As we talk more about what these badges might look like, and how they could be earned by people in the team, I talk about how there might be two different ones - a badge for Senior researchers that recognised cultural authority and existing experience, and a badge for younger people who do a lot of the face-toface facilitation of interviews and meetings and other aspects of the research process, but who are also keen on receiving more training and support.

The idea of the second badge is particular welcomed by one of the members of the team who is quite actively trying to build himself a small business as a cross-cultural consultant in the community, available to work with all sorts of visitors needing assistance when arriving for research, or other government and service delivery work. But amidst this enthusiasm, I realise there is another young man in the car who would be missed out by both of these badges. This 'junior mentoree' is a young man recently out of school, working with his family just learning what it means to collaborate with university staff and Balanda (non-Indigenous people) visiting this Yolnu community.

Later that day, we sit on the veranda of the senior woman's house, and talk about the issue of micro-credentialing some more. She insists that this young man, who is often very quiet as we go about our work, is an important part of the team. He is generally there carrying the $i P a d$, and recording or taking photos of what we do. At the same time, he is also watching and learning, seeing how the more experienced people go about doing what they do. His role is crucial, she tells me, because the reason for doing research work is to provide a role model to younger people, to show them the way so they can work together with Balanda organisations themselves in the future. If the young people are not watching the work, then an important teaching and learning opportunity is going to waste. 
So, we realised that we had to create another badge to capture this important research role, and we named this one 'Indigenous Research Collaborator'. Once this third badge fell into place, it suddenly felt like we had the set now. There were different roles and competencies involved in working as this research team, and these roles could all be recognised even while they were not superimposable or directly connected as a linear learning pathway (e.g. a junior person could not achieve a senior badge if they worked hard, it was a different order of recognition. However, a research collaborator could progress to the intermediate credential of communitybased researcher). The point is that the three badges are parts of a whole-and that's it. That is the qualification, the educational services product, that the students as clients of the university are being sold.

Figure 1. Indigenous Researcher Micro-credentials
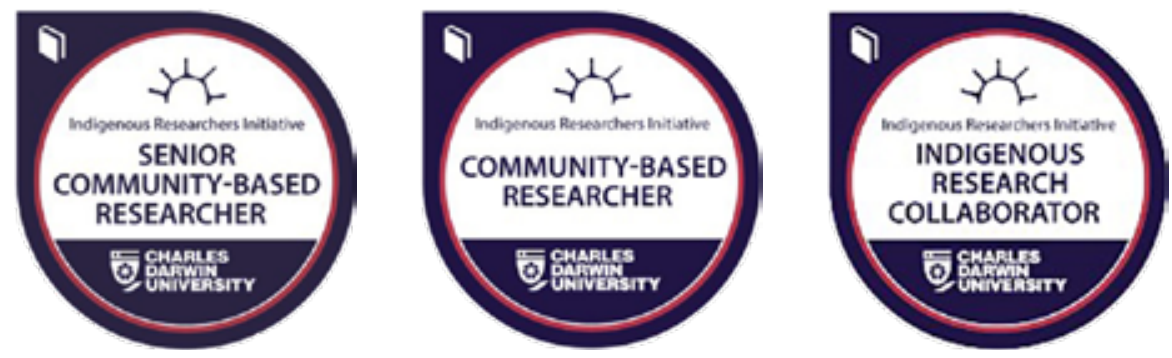

Source: Indigenous Researchers Initiative website (https://iri.cdu.edu.au/credentials/)

It can be an assumption within the western academy that education and training focus on the development of the individual learner. The role of the institution is to take this student, who knows little, and fill them up to become an autonomous authority able to then carry their expertise to a variety of contexts (Christie, 2009). When working as part of a team developing micro-credentials suitable for the needs of community-based researchers, I found that shifts in the configuration of these arrangements needed to occur. In delivering the research services, the arrangement of this team is important not only so that work can be carried out, but so that appropriate positions for learning and responsibility in-place can be maintained. Accommodating both of these needs would help generate value on the ground that exceeds the delivery of research services products but is also connected to them. However, to as to be able to work this double accountability and benefit, a final step was required.

\section{Story Three: Authorising arrangements}

Sometime later I was enjoying some quiet time in the shade with some senior ladies who had been involved for many years in the Yolnu research organisation Yalu' Marngithinyaraw. They were talking about a meeting that had recently happened at the Yalu' office in Galiwin'ku where CDU credentials, and recognition from universities for community-based researchers, had been discussed.

They were confused and a little agitated about some conversations that had occurred, and were seemingly trying to work out what had happened. At the meeting, a senior man, not a researcher, had raised lots of questions about how the credentialisation of research expertise 
should work when being offered by a Western institution. It seemed he had been trying to make the point that: yes, it's great for Yolnu to get recognised for their research achievements in the university. But then back here in the community, when these same people are with family, and hanging around at the shop, no one knows what they have done. No one knows that they have that respect and recognition from the Balanda world, and this would be a strange situation. He suggested that the researchers needed to be acknowledged at home, in the community, as well. And if they weren't recognised properly, then they couldn't do their research work well, because others wouldn't co-operate. So, in relation to the design of working micro-credentials, these objects needed to also embed the capacity for accrediting researchers in ways that make sense for Aboriginal people, and their understandings of how to accredit levels of expertise or competency in-place.

I started to think more about ways of supporting recognition across both Yolnu and Western academies. Of course, as Charles Darwin University seeks to offer dual-academy ${ }^{5}$ education services as part of its course offerings, it is important that the university takes note of this realisation. Amongst various discussions around this issue that subsequently arose, there was one solution that stood out and was what we adopted. The shift was to recognise that every badge awarded would require the authorisation of two signatories - a senior Indigenous authority, and a CDU College Dean. This way, any badge awarded would recognise researchers as qualified by the university, as well as qualified through a process recognised as legitimate by a senior Indigenous authority. This senior authority would need to be related in the right way to the badge earner through gurrutu (kinship) and be satisfied they could carry out communitybased research in a manner appropriate for Yolnu. The act of adding this second signatory helped to respond to the issue that the old man had raised - it enabled the researcher's level of achievement to be witnessed and recognised as real by Yolnu and in the place where the researcher lived and worked. This would also mean that as they continue to earn salary through the authorised delivery of research services products, they are also observing Yolnu authority and law.

\section{Making and doing micro-entrepreneurial services economies}

So, what does it mean to be 'Making and Doing STS' through these arrangements and situations described here? How do they help to elucidate the making and doing of STS as processes where both scholar and scholarship get made and done together? As a way of inquiring into our initial on-ground inquiries into how to design the badges, telling these stories while also interspersing them with a second-order level of commentary, emphasises rupture while helping certain elements come to the fore. These dual voices work to situate our practices in the assemblage of micro-entrepreneurial services economies on the ground, and in the construction (or refusal) of certain arrangements normally assumed to be central to microenterprise and its functioning, as well as to educational services products and their delivery. As a researcher, now narrating this series of events in an academic paper, there has been no 'getting away' from the market-based economies running through these stories. The delivery of research services, and the design of forms of accreditation which support these services and their providers, help to maintain and expand Northern Territory services economies. Of course, the value and/or potential damage, of such economisation has been hotly debated

5 Dual academy refers to the character of educational services which recognise themselves as engaging two different, and equally formal, academic traditions - Western and Indigenous (or more specifically in this case, Yolnu) 
in literature around hybrid economies (Altman, 2001), and the delivery of natural resource management services by Aboriginal Ranger groups in northern Australia (Fache, 2014; Fache and Moizo, 2015). However, the analysis briefly presented here leads in a different direction.

Instead, I suggest it is productive to see these activities as explicitly disassembling the "disposition of the self-regulating citizen-subject: entrepreneurial, adaptive and self-reliant" (Prentice, 2017), often recognised as lying at the heart of neoliberal market economies, and their micro-entrepreneurial expression as 'gig' or 'sharing' economies. This policy 'dispositif' (Foucault, 1980) is well established in Australia but there are as yet no systematic studies of microenterprise development in Australia and the roles of the micro-credential in this. However, in the on-the-ground collaborative design practices traced out in the stories above, we see evidence of strong resistance to, and subversion of, the 'autonomous citizen subject' as essential to research services micro-enterprise in Arnhem Land. Rather, by the end of the process, the providers of research services recognised by the credentials were not autonomous individuals. They were small intergenerational teams preserving correct relations of pedagogy and correct collaborative action within Yolnu society and research practice. Similarly, the systems for accrediting community researchers via a single university authority were reworked. This process would have produced a commensurability between individual researchers as they were acknowledged by this one authorising figure. However, once there was also a requirement for a senior Indigenous authority to award a credential, relations of kinship became relevant, and there the universalising pretentions of the university are subverted It cannot be any one particular Indigenous authority than can act as a signatory for all, rather the right signatory would have to be sought for the particular awardee in question.

Downey and Zuiderent-Jerak suggest that "the scholarship of STS making and doing treats practices of engagement and reflexivity as intimately linked and builds on both by calling attention to the two way, or multiple-way, travels of knowledge production and expression. The scholarship of STS making and doing is about both care and learning" (2017,6 p. 245). Effecting a form of relational empiricist inquiry in my display here of both stories and commentary, I have also sought to make evident these relations of engagement and reflexivity, and care and learning that Downey and Zuiderent-Jerak suggest are implicit within STS making and doing. This reflexive situated practice disassembles and dissolves some of the solidified categories of institutions and economy to allow possibilities of re-assemblage in divergent, particular, and amenable ways.

\section{References}

Altman, J. (2001). Sustainable Development Options on Aboriginal Land. The Hybrid Economy in the Twenty-First Century. Canberra: Centre for Aboriginal Economic Policy Research.

Baporikar, N. (Ed.). (2015). Handbook of research on entrepreneurship in the contemporary knowledge-based global economy. IGI Global.

Bow, C. (2019). Collaboratively designing an online course to teach an Australian Indigenous language at university. Babel, 54(1/2), 54-60.

Christie, M. J. (2009). Engaging with Australian Indigenous Knowledge System: Charles Darwin University and the Yolnu of Northeast Arnhemland. Learning Communities: International Journal of Learning in Social Contexts, (7), 23-35.

Downey, G. L., \& Zuiderent-Jerak, T. (2016). Making and Doing: Engagement and reflexive learning in STS. In Felt, U., Fouché, Miller, C. A., \& Smith-Doerr, L. (Eds.). Handbook of Science and Technology Studies, pp 223-250. Cambridge, MA: MIT Press 
Fache, E. (2014, July). Caring for country, a form of bureaucratic participation. Conservation, development, and neoliberalism in Indigenous Australia. In Anthropological Forum 24:3, 267-286, DOI:10.1080/00664677.2014.939576

Fache, E., \& Moizo, B. (2015). Do burning practices contribute to caring for country? Contemporary uses of fire for conservation purposes in indigenous Australia. Journal of Ethnobiology, 35(1), 163-183.

Foucault, M. (1980) 'The Confessions of the Flesh', in Foucault, M. (ed.) Power/Knowledge: Selected Interviews and Other Writings, pp. 194-228. New York: Pantheon Books.

Gibson, Hannah. (2016). Top of the Heap: Helen Verran. Retrieved May 30, 2020, from Somatosphere website: http://somatosphere.net/2016/top-of-the-heap-helen-verran.html/

Howard-Wagner, D., Bargh, M., \& Altamirano- Jiménez, I. (2018). From new paternalism to new imaginings of possibilities in Australia, Canada and Aotearoa/New Zealand: Indigenous rights and recognition and the state in the neoliberal age. In In D. Howard-Wagner, M. Bargh, \& I. Altamirano-Jiménez (Eds.), The Neoliberal State, Recognition and Indigenous Rights: New paternalism to new imaginings. (pp. 1-42). Canberra: ANU Press.

Law, J. 2004. After Method: Mess in Social Science Research. London: Routledge.

Prentice, R. (2017). Microenterprise development, industrial labour and the seductions of precarity. Critique of Anthropology, 37(2), 201-222.

Spencer, M and Christie, M. (2020) Community Planning and Development Program: Ground Up Monitoring and Evaluation, Interim Report, Northern Institute, Charles Darwin University.

Spencer, M., Hanieh, S., Biggs, B., and Christie, M. (2019) Hope for Health: Evaluation Report, November 2019, Northern Insitutute, Charles Darwin University.

Verran, H. (2001). Science and an African logic. Chicago: University of Chicago Press.

Verran, H (2013). Numbers performing nature in quantitative valuing. NatureCulture 2: 23-37. 